\title{
Upper Flexor Surface
}

National Cancer Institute

\section{Source}

National Cancer Institute. Upper Flexor Surface. NCI Thesaurus. Code C147166.

Pertaining to the upper portion of the surface on the same side of the joint when it bends. 